\title{
Den tikkende miljøbombe i øst
}

\section{Morten Hansen}

\section{Tæt på os lurer en glemt miljøbombe - forældede pesticider, som på den ene eller den anden måde kan finde vej også til Danmark. Problemet sidestil- les fra flere sider med den trussel mod klimaet, som den globale opvarmning vil medføre}

De fleste kender klitgryden ved Høfde 42 på Harboøre Tange, et område på 22.000 kvadratmeter, lige ud til Nordsøen, som er stærkt forurenet med kemikalieaffald. Her er der gravet et depot ned med omkring 160 tons pesticidaffald, primært $\mathrm{Pa}$ rathion, bedre kendt som Bladan, fra Cheminovas produktion i 1950"erne. I december 2013 afsluttes et pilotprojekt som skal undersøge mulighederne for at rydde op. Det forventes, at oprydningen vil tage fem år og blive en bekostelig affære. Problemet er, at giftstoffer siver fra depotet til grundvandet og der er risiko for, at det siver ud i Nordsøen.

Det er alvorligt problem i Danmark og en gammel nyhed. Men faktisk er depotet på Harboøre Tange kun en lille og overskuelig fisk i det globale hav af lignende kemiaf- faldsdepoter, som fortiden har efterladt.

Alene i den østlige del af Europa og Centralasien - de 15 nu selvstændige lande, som var en del af Sovjetunionen - er omfanget af kemikalieaffald anslået til op imod 300.000 tons fordelt på omkring 10.000 lagerpladser. På verdensplan er tallet oppe på 500.000 tons, men Afrika, Sydøstasien, Central- og Sydamerika er ikke så hårdt ramt. I disse regioner har man simpelthen ikke importeret eller produceret så store mængder.

Værst ser det ud i de tidligere sovjetrepublikker, med Ukraine og især Rusland som de hårdest ramte. Jo længere mod øst, desto værre er det og des mindre styr er der på, hvor depoterne befinder sig. Registreringen er mangelfuld og manipulerede 
tal optræder i officielle statistikker over, hvor meget der reelt findes.

\section{Lig global opvarmning}

Problemet sidestilles af forskere med den globale opvarmning i sit omfang og som en reel trussel mod menneskeheden. Derfor arbejder FAO, FN's fødevare- og landbrugsorganisation, på at fjerne pesticiderne. FAO's overordnede bekymring er, om jorden er i stand til at producere fødevarer nok til en befolkning på ni milliarder mennesker i fremtiden. De enorme mængder kan nemlig ødelægge landbrugsjorden. Måske overraskende for de fleste så har NATO også de forældede pesticider på dagsordenen.

Et af skrækscenarierne er, at terrorister bruger forældede pesticider som våben. Det er frit tilgængeligt, det er ekstremt farligt og det er relativt simpelt for ikke at sige pærelet, hvis man er i stand til at sprede det - enten i grundvandsforsyningen, $\mathrm{i}$ landsbrugsproduktionen, i en bombe eller på en anden måde, så giften spredes. Derfor har NATO også engageret sig i projekter, der skal fjerne forældede pesticidlagre.

Et af projekterne er i Moldova, som jo ikke er medlem af forsvarsalliancen, hvor NATO sammen med blandt andre UNDP har stået for at fjerne mere end 3.000 tons forældede pesticider. Det er halvdelen af den mængde, Moldova kæmper med. Et land, der i størrelse og be- folkningstal er lidt mindre end Danmark, ikke medlem af EU og meget fattigt, men alligevel skal forsøge at overkomme en udfordring i størrelsesordenen Høfde 42 gange 20. Og så er Moldova ikke engang blandt de hårdest ramte i regionen.

Hvor kommer de utrolige mængder af giftigt affald fra? Og hvilke konsekvenser vil de få - miljømæssigt og politisk, hvis ikke problemet tages alvorligt i den nærmeste fremtid?

\section{Sovjetisk arv}

I Sovjetunionen producerede og fordelte man store mængder af gødning og pesticider for at øge landbrugsproduktionen. Fordelingen skulle stimulere og motivere til en større produktion, men medførte samtidig en hamstring af pesticider lokalt. Hundredtusindvis af tons pesticider blev spredt ud over unionen. I Sovjet-tiden var der rimelig godt styr på, hvor og hvor meget, der var fordelt. Men med Sovjetunionens sammenbrud ophørte registreringen, og samtidig forsvandt en del af de data, man på daværende tidspunkt havde.

Nu er der gået mere end 20 år, og kemikalierne er begyndt at sive mod grundvandet, de lagre, de er opbevarede $i$, er ved at forfalde, og ingen har reelt overblik over situationen.

Sovjetunionens sammenbrud efterlod tusindvis af steder med små lagre af pesticider til den lokale 
egns landbrugsproduktion. Det kan være et, to eller måske ti tons pesticider, tiltænkt landbrugsproduktionen, ofte opbevaret i en lagerbygning, som siden sammenbruddet har stået uberørt og dermed er forfaldet. Faktisk må nogen rejse rundt til landsbyerne for at finde ud af, om der er efterladte lagre, hvis der skal skabes et overblik. Som regel ved den lokale befolkning, om der findes 'farlige' steder på egnen, som man helst undgår.

En anden type lokationer er decideret affaldsdepoter og fremstillingssteder. Lige som vi tidligere har gjort det i Danmark, så gravede man simpelthen spildprodukter og uanvendelige eller forældede lagre af pesticider ned. Også fortegnelserne over nogle af disse depoter er forsvundet, men de fleste ved man dog hvor er.

Her mere end 20 år efter kommunismens sammenbrud står vi med et meget alvorligt problem, som er en trussel mod det globale miljø, mod fødevareforsyningen og fødevaresikkerheden. Vi har ikke så lang tid at løbe på, flere steder, for eksempel i Kalusj i Ukraine, er truslen akut. Området blev ramt af oversvømmelser i 2008, og nu arbejder man fra flere sider på højtryk for at fjerne de sidste tusinde tons affald, inden en ny oversvømmelse risikerer at forurene ikke bare lokalområdet, men også floden Dniestr, der løber gennem det vestlige Ukraine og Moldova og har sit udløb i Sortehavet.

\section{Forældede pesticider}

Hvad er forældede pesticider egentlig?

Forældede pesticider - på engelsk Obsolete Pesticides, deraf forkortelsen OP eller POP, hvor P'et står for persistent, er forældede, organiske pesticider, der kan eksistere meget længe i naturen uden at forsvinde eller blive opløst. Pesticider er forældede, når de enten er blevet uanvendelige på grund af alder - de mister nemlig deres effekt, som tiden går - eller hvis de bliver omfattet af et forbud.

I 2001 vedtog man Stockholmkonventionen, der forbyder tolv organiske miljøgifte, som regnes for de tolv farligste i verden. De kaldes undertiden for 'det beskidte dusin'.

Det drejer sig for eksempel om DDT, PCB og HCB. At man er holdt op med at producere miljøgiftene og har indført både eksport- og importforbud på verdensplan, betyder ikke, at de er forsvundet. Depoter og lagre er der stadig. Efterhånden som den emballage, de oprindeligt blev opbevaret i, nedbrydes, kommer katastrofen nærmere. Typisk er affaldet gravet ned i tønder, der ruster, mens pesticiderne kom i sække, som er ved at være mørnet.

Egentlig er pesticiderne produceret for at øge fødevareproduktionen, men det har vist sig, at de er meget skadelige og kun langsomt nedbrydes i naturen og i kroppen, derfor sker der en ophobning af 
stofferne hos både planter, dyr og mennesker.

Det er et globalt fænomen, der spredes gennem atmosfæren og via vandets cirkulation på jorden. Selv i de arktiske egne, hvor der aldrig er blevet anvendt eller produceret pesticider, ser man en ophobning hos rovdyr og fisk.

Følgevirkningerne er nedsat immunforsvar, hormonforstyrrelser, cancer, nedsat vækst og misdannelser ved reproduktion, hvis reproduktion overhovedet er muligt, for giften går også ud over sædkvaliteten. I for store doser dør man af en forgiftning - Bhopal i Indien var en pesticidfabrik, hvor et udslip slog tusindvis af mennesker ihjel. Det er altså noget virkeligt farligt stads, og der er rigtig meget af det. En skefuld - fem milliliter - forældede pesticider kan forurene drikkevandet til 15.000 mennesker i et år.

Et af de værste eksempler på pesticidforgiftninger er fra Tyrkiet i 1950 'erne. Landet var plaget af hungersnød og som hjælp sendte USA hvedemel, så man kunne bage brød. Men kornet var blevet overfladebehandlet med pesticiden HCB for at undgå svamp. 500 mennesker døde af at have spist brødet. Yderligere 4.000 blev syge.

30 år efter undersøgte man brystmælk i regionen. Og her var indholdet af HCB stadig syv gange højere end i ellers lignende områder. $\mathrm{Og}$ 150 gange højere HCB- indhold end det er tilladt i komælk.

\section{Dansk svinefarm}

I landsbyen Kalusj i det nordvestlige Ukraine, ikke langt fra grænsen til Polen, har der været ikke mindre end otte kemikaliefabrikker. Hele området er kontamineret og indeholdt indtil 2008 mindst 22.500 tons primært HCB affald. Der er stadig 57.000 tons tilbage, blandt andet et nedgravet depot med HCB i tønder. Myndighederne i Ukraine er i gang med at rydde op, men der mangler stadig meget.

I den konkrete sag er der mange tråde til Danmark. For eksempel er en dansk ejet svinefarm placeret kun en kilometer fra et af de nedgravede depoter i Kalusj, nedenstrøms. Det vil sige vandet løber i en kanal få meter fra depotet og videre forbi svinefarmen. Svineproduktionen går ikke til Danmark, men det er et dansk projekt, som den selvejende statslige fond IFU har investeret 30 millioner kroner i.

Forskere, FAO, NGO'er og lokale politikere er meget nervøse for Kalusj. Tusindvis af tønder med HCB har været gravet ned i mere end 20 år. Det er begyndt at sive fra tønderne, og nu truer en forurening af grundvandet. Det er ganske tæt på floden Dnestr, og dermed truer en forurening med at ødelægge drikkevandsforsyningen til Moldova og det vestlige Ukraine, inden Sortehavet bliver ramt. Det kan forhindre millioner af mennesker i at få rent drikkevand. Jorden vil blive forurenet, 
så den ikke er egnet til dyrkning af afgrøder. I al hast har man transporteret tusindvis af tons til destruering i blandt andet Polen og England.

Der er nemlig ikke så mange steder, man kan destruere det farlige affald, og slet ikke i så store mængder. Et af stederne er i Nyborg Værket.

Transporterne fra Kalusj til Gdansk, hvor en stor del af destrueringen er foregået ved forbrænding af affaldet, er flere gange blevet afsløret i ikke at foregå efter sikkerhedsstandarder, som påkrævet for at undgå ukontrollerede spredning. Billeddokumentation viser lastbiler med kemikalieaffald, hvor der er gået hul på indpakninger. Desuden var store mængder opmagasineret ved havnen i Gdansk, 14.000 tons. En oversvømmelse ville kunne sprede kemikalieaffaldet i Østersøen. Samtidig har der været problemer med restprodukterne efter afbrændingen. Således er slagger fra forbrændingen hældt i en grusgrav i nærheden af Gdansk.

\section{Omkostningerne}

Selve forbrændingen rejser nye problemer. Afbrændingen skal ske under meget kontrollerede forhold ellers skabes der dioxiner i røgen, som så udledes i miljøet som en luftbåren gift - dioxin. Et vigtigt aspekt i destrueringen af de forældede pesticider er økonomien. Det er ikke billigt at skaffe sig af med fortidens synder.
International HCH \& Pesticides Association (IHPA), der er et uafhængigt og apolitisk netværk, har beregnet prisen til 3.000 euro pr tons. Det betyder at omkring en milliard euro vil kunne fjerne problemet helt fra Europa og Centralasien. Umiddelbart lyder det af mange penge, men når man sammenligner med, hvad det kan koste, hvis man ikke gøre noget, er det småpenge.

Nitrofen-skandalen i Tyskland giver et fingerpeg om, hvor dyrt det er $i k k e$ at rydde op: Et lager i det tidligere $\varnothing$ sttyskland blev brugt til at opbevare foderstoffer. Tidligere havde lagret været brugt til at opbevare plantegiften Nitrofen. Foderstoffet blev kontamineret med Nitrofen, og pludselig blev der registreret Nitrofen i økologiske æg, kyllinger, kalkuner, svin og i mælk - i flere lande. Det lammede salget og krævede, at en lang række fødevarer blev trukket tilbage og destrueret. Ingen mennesker kom til skade, men omkostningerne var enorme. Det tyske landbrugsforbund har senere estimerede omkostningerne til at være i omegnen af 540 millioner euro, eller halvdelen af prisen for at løse problemet helt. Her var tale om kun ét og indtil da ukendt, forurenet lager. Vi ved, at der er omkring 10.000 af disse steder i Østeuropa og Centralasien.

Set i det perspektiv er der tale om en gigantisk økonomisk trussel både for de lande, der eksporterer fødevarer, men også for lande, som im- 
porterer fødevarer. I Danmark var Fødevarestyrelsen også nødt til at fortage ekstra kontroller, lige som man gjorde det i mange andre lande efter Nitrofen-skandalen. Men for et enkelt land kan det være økonomisk altødelæggende, hvis eksporten bliver lammet. Det leder os helt naturligt til spørgsmålet om de politiske konsekvenser. For kan EU og Danmark lade være med at gøre noget ved problemet?

\section{Politiske konsekvenser}

Også politisk er de forældede pesticider en problematisk størrelse. På grund af de potentielt voldsomme konsekvenser kan problemet ikke ignoreres meget længere. Det er nu mere end 20 år siden, at Sovjetunionen brød sammen. De fleste steder har depoter og lagre altså ligget uberørt i mere end 20 år.

Til sammenligning gik der 29 år fra Cheminova og staten holdt op med at bruge depotet på Harboøre Tange til, at man i 1981 opdagede, at giften sivede ned i grundvandet, og fiskene begyndte at dø, og mågerne blev syge. Faktisk var det en lokal fisker, der gjorde opmærksom på problemet. Grundvand og fødevareproduktion er nødvendigheder, som, hvis de forsvinder, kan skabe massedød og ødelæggelse, krige og store folkevandringer.

Ingen er nok helt i stand til at gennemskue de politiske konsekvenser, hvis for eksempel ti millioner mennesker i det vestlige Ukraine og Moldova pludselig ikke har mere vand på grund af en akut, menneskeskabt forurening. Alene de økonomiske omkostninger vil være astronomiske.

Hvis Kalusj bliver oversvømmet igen, og det denne gang betyder, at pesticider og affald bliver skyllet væk, så er konsekvensen i den størrelsesorden - ti millioner mennesker uden vandforsyninger.

Samtidig er der en udtalt modstand mod import i vesten og ikke uden grund. Import og eksport af forældede pesticider er tilladt ifølge Stockholm-konventionen, hvis det er for at destruere giften.

Men det er selvsagt farligt at transportere det rundt i verden og skaber både miljømæssige og politiske problemer.

De fleste kan huske sagen om skibet Beluga Fascination, der blev stoppet af daværende miljøminister Karen Ellemann efter et pres fra offentligheden. Skibet medbragte 6.100 tons HCB-affald fra Australien, der skulle sejles til Nyborg for at blive forbrændt på det tidligere KommuneKemi. Det er den samme kemiske forbindelse som i Kalusj HCB.

Man er nødt til at skelne mellem risikoen ved at transportere store mængder rundt på verdenshavene og så på miljøpåvirkningen, når det bliver destrueret i for eksempel $\mathrm{Ny}$ borg. Under alle omstændigheder viste sagen, at det politisk er meget 
svært at stille teknologi til rådighed, hvis det betyder, at så giftigt affald bliver bragt ind i landet, selvom formålet er destruktion. Samtidig er det bemærkelsesværdigt, at et så relativt veludviklet land som Australien - både økonomisk og teknologisk, ikke er i stand til selv at destruere HCB og andet ekstremt farligt kemikalieaffald. I ly af skibet fra Australien sejlede der et andet skib fra Ukraine gennem Sortehavet og Middelhavet til Southampton i England med kemikalieaffald fra Kalusj.

\section{Krav fra EU}

I Vesteuropa har vi for længst fået styr på tidligere tiders efterladenskaber fra pesticidproduktion. Derfor har det været et krav i optagelsesforhandlinger med potentielt nye medlemslande i EU, at de fik løst problemerne med forældede pesticider.

Nogen steder har det ført til, at man lokalt brændte kemiaffaldet af i lokale forbrændingsanstalter, som ikke var beregnet til formålet. Ved forkert afbrænding omdannes de forældede pesticider til for eksempel dioxin og driver ud i atmosfæren.

Konsekvenserne er mangfoldige, hvis ikke der snart gøres noget. De forældede pesticider kan ødelægge et lands $\varnothing$ konomi, de kan skade generationer og de kan gøre fødevaresikkerheden og fødevareforsyningen meget ustabil eller ligefrem ikke eksisterende.
Hvis et skib forliser med 6.000 tons $\mathrm{HCB}$, der så spredes i havene, er konsekvenserne helt uoverskuelige. En sådan katastrofe har vi heldigvis ikke set, men faren er reel. Ser vi derimod på, hvilke miljømæssige konsekvenser, der er ved ikke at gøre noget ved de forældede pesticider, så vender vi tilbage til Harboøre Tange og Høfde 42, som et lokalt eksempel på konsekvenserne. Giften er sivet ned i grundvandet, der er bade- og fiskeforbud og området er kontamineret, så der ikke kan dyrkes afgrøder. Man kan godt passere gennem området, men det anbefales, at man ikke tager ophold.

Store områder bliver ødelagt, så der ikke kan dyrkes afgrøder, drikkevandet forurenes, giften ophobes i fødekæden med en lang række negative konsekvenser til følge. Biodiversiteten falder markant, og vi udvikler flere tilfælde af cancer.

\section{Græshoppe-effekten}

Langsomt spredes forureningen og påvirker alle egne af kloden. Det kaldes græshoppe-effekten, som betyder, at giften følger med i vandets cyklus, når det henholdsvis regner og fordamper, så det ender i sneen over de arktiske egne. Der er for eksempel aldrig produceret eller importeret pesticider i Grønland, men alligevel er det muligt at måle en ophobning af pesticider hos mennesker og dyr i Grønland, og faktisk mener man, at pesticider er skyld i, 
at isbjørnene i Østgrønland udvikler mindre kønsorganer.

Nogle steder i verden har man som sagt afbrændt forældede pesticider i almindelige forbrændingsanlæg. Afbrændingen er i sig selv et problem, hvis det sker ved forkerte temperaturer, så dannes der dioxiner, som spredes i atmosfæren.

Dioxiner har nogenlunde den samme effekt som pesticider på mennesker og dyr - misdannelser, cancer og forplantningsbesvær. Agent Orange, som amerikanerne sprøjtede ud over de vietnamesiske skove under Vietnam krigen, er nok en af de bedst kendte dioxinholdige gift.

En sidste og meget skræmmende trussel er, at producenter i de fattige og underudviklede lande bruger af depoterne for at øge produktionen af deres afgrøder, selvom kemikalierne ikke vil have nogen effekt. Problemet i denne sammenhæng er, at pesticiderne ikke nødvendigvis bliver opdaget, hvis de er blevet brugt.

IHPA foretog en stikprøve på et lager i Usbekistan i 2009, organisationen krydstjekkede de fundne pesticider med den europæiske fødevarekontrol, EFSA's liste over pesticider, der kontrolleres for. 75 pct. af pesticiderne i dette lager ville ikke blive opdaget med den nuværende kontrol, fordi pesticiderne er så gamle, at de ikke figurer på EFSA's kontrollister. Flere af forbindelserne er ikke blevet brugt i det vestlige Europa i over 30 år. Derfor figurer de ikke på listerne over kemikalier, man skal tjekke for. Det skaber en potentiel risiko for, at vi på et eller andet tidspunkt får importeret fødevarer, som er forurenet med forældede pesticider.

IHPA har registret eksempler på sager, hvor forældede pesticider er blevet fjernet fra lagre, pakket i ny emballage og solgt til lokale landmænd.

\section{Hvad kan gøres?}

I november 2013 blev det 12. Internationale $\mathrm{HCH}$ forum gennemført i Kijev, Ukraine. Hvert andet år samles netværket IHPA til en konference for at gøre status over udviklingen og skabe opmærksomhed omkring problemet for at få både offentligheden og politikkerne i tale. Kijev var valgt som værtsby, da Ukraine er det gode eksempel på, at der sker fremskridt. Ukraine som nation er selvfølgelig også hårdt presset af situation i Kalusj.

Mama 86 - som er en miljøorganisation, der i sit udgangspunkt var en gruppe unge mødre, som gik sammen efter Tjernobyl-katastrofen i 1986 for at gøre en indsats, da de var bekymrede for de problemer, som Tjernobyl-ulykken medførte for deres børn - har valgt de forældede pesticider som det vigtigste fokusområde, nu hvor der er rimelig godt styr på konsekvenserne efter den eksploderede reaktor - det er simpelthen den største trussel, set med 
Mama 86 øjne. Men bortset fra Ukraine, så er der ikke sket ret meget i de senere år i regionen. Situationen er status quo.

Der er brug for mere opmærksomhed omkring problemet i offentligheden og politisk. På det praktiske plan er der brug for registrering og identifikation af lokaliteterne, handlingsplaner for løsninger, penge og samarbejde på tværs. Derfor er det bemærkelsesværdigt, at kun en eneste vestlig politiker havde fundet vej til Kijev i november 2013. Det var det danske socialdemokratiske medlem af Europa-Parlamentet, Dan Jørgensen.

\section{Nye metoder}

Derimod havde den branche, der arbejder med at destruere forældede pesticider og andet kemikalieaffald, fundet vejen til Kijev. I løbet af de seneste år har man udviklet en lang række nye metoder, som er kommercialiseret, til destruktion. Man har for eksempel udviklet mobile løsninger, der gør det teknologisk muligt at flytte destrueringsanlæggene rundt i verden, hvor der er behov for det.

Et newzealandsk firma har udviklet et system, hvor bakterier æder og nedbryder visse pesticider, hvis de findes i jord, så det er muligt, at løse problemet også inden det er for sent eller inden det bliver for dyrt, vel at mærke uden at vi skal løbe risikoen ved at sejle giften rundt.

\section{Fødevarerisici}

Dan Jørgensen sagde på konferencen i Kijev: "Dette er bestemt en af de største miljømæssige trusler vi har. Helt sikkert i Europa og i Østeuropa, måske i hele verden. Det er meget vigtigt, men det er også glemt. Mange mennesker i de lande, der er ramt, kender ikke problemet og mange i de lande, der kan hjælpe, kender ikke til problemet.

Det er et stort problem - med jord, der er forurenet, vand der bliver ødelagt. Nogen steder er det allerede sket, andre steder vil det snart ske. Andre steder igen kan vi forhindre det i at ske, hvis vi gør noget. Risikoen for at fødevarer bliver ødelagt er stor. Men det er også en $ø$ konomisk risiko.

Ved I hvad der sker, hvis et land i Europa bliver udsat for en fødevareskandale? Eksporten vil stoppe. Der vil blive retslige efterspil, og selv længe efter vil der være konsekvenser for markedet. Så derfor er vi ud fra rationelle økonomiske betragtninger - nødt til at gøre noget ved disse problemer. Hvis man skal gøre noget ved problemet, er man nødt til at kende omfanget. Så det første er nationale handleplaner.

Hvis vi skal være ærlige, så er der ikke fokus og opmærksomhed nok på problemet. Ikke engang i de lande, der er ramt. Så fra EU skal vi dels komme med penge, men også med politisk pres på de nationale myndigheder i de berørte lande. Det 
er meget vigtigt, at de involverede lande laver deres egne handleplaner og strategier. Derfor skal landene selv etablere systemer, der kan løse problemet. Med støtte fra os i Vesteuropa. For det første mener jeg, at risikoen ved at transportere affaldet rundt er meget stor. For det andet er udgifterne nok for store for de berørte lande, og endelig er det ikke populært for en politiker at sige ja til, at giftigt affald bliver transporteret til ens eget land for at blive destrueret. Det skaber stor modstand. Vi skal give dem økonomisk og teknisk støtte, så problemerne bliver løst lokalt. For vi skal undgå disse farlige transporter".

Kevin Helps, chef for FAOs pesticid-afdeling, sagde i Kijev: "Det er en tikkende bombe. Vi anslår at der globalt er 500.000 tons. Hovedparten af disse kemikalier bliver opbevaret i underjordiske lagre. Det var praksis den gang, også i Vesteuropa. $\mathrm{Nu}$ ved vi, at det giver problemer.

Vi bliver bedt om at producere mere føde på mindre og mindre jord. Det er konsekvensen af de forældede pesticider og farlige depoter fra produktionsanlæg. I 2050 skal vi producere mad nok til ni milliarder. Men kontamineringen gør, at de dyrkbare arealer bliver mindre og mindre. Det er det problem, vi arbejder med i FAO. Vi arbejder for en bæredygtig intensivering af fødevareproduktionen. Ingen siger, lad være med at bruge pesticider. Vi er nødt til at bruge pesticider, men det skal ske, så det ikke skader".

Den fremtrædende danske ekspert, Finn Bro-Rasmussen, professor emeritus, sagde om transport af de farlige kemikalier: "Hvad er risikoen for, at det kommer ud for et uheld? Det er man ikke forberedt på. At det så er en tikkende bombe, der rent faktisk er gået af, er man ikke forberedt på. Her taler vi om det HCB, der kom her fra Ukraine.

Jeg mener bestemt, at menneskeheden er truet af de her kemikalier. Det er lige så stort som klimaforandringerne. Hvis en forurening er ude i Østersøen, så tager det 50 år at få den halveret. Efter 100 år vil der være en fjerdedel tilbage. Hvis man brænder dem og brænder dem for hurtigt, så får man dem gendannet i skorstenen sammen med dioxin. Så skal transporten kontrolleres og forbrændingen skal kontrolleres, så vi ikke genskaber HCB'en i skorstenen.

Jeg tvivler på, at det der ligger i Gdansk, er i stand til at forbrænde det kontrolleret. Jeg tror ikke på, at man kan forbrænde HCB så hurtigt, som de gør i Gdansk uden at gendanne HCB”.

Morten Hansen er journalist og cand. comm. Han deltog $i$ HCH Forum $i$ Kijev $i$ oktober. Han har fulgt udviklingen med de forceldede pesticider i en årrakke. 